\title{
Tafsir Esoterik Kiai Shaleh Darat Tentang Salat
}

\author{
Oleh: Ahmad Aly Kaysie \& Indal Abror
}

Email: indal.abror@uin-suka.ac.id

UIN Sunan Kalijaga, Yogyakarta

\begin{abstract}
Abstrak
Menjadi satu dari tiga ulama-pejuang kepercayaan Pangeran Diponegoro dan mendapat gelar "guru para ulama Jawa" dengan tiga muridnya menjadi pahlawan nasional (Kiai Hasyim Asy'ari, Kiai Ahmad Dahlan, Raden Ajeng Kartini) menjadikan Kiai Shaleh Darat tokoh yang penting dikaji (untuk kemudian diteladani) pemikirannya. Dari sekian banyak karya beliau, Faiḍ al-Rahmān fì Tarjamah Kalām Malik al-Dayyān dan Kitab Lațāif al-Ṭahāra wa Asrār al-Siāăh adalah dua kitab yang menjelaskan salat secara sufistik-lokalistik. Dikatakan sufistik karena terdapat usaha serius untuk mengungkap makna isyari, dan lokal karena ada ungkapan 'atine ... ingdalem pasar' dan beberapa lainnya dalam usaha melakukan 'pembumian' makna ayat. Terlebih lagi, kedua kitab tersebut ditulis dengan aksara pegon yang jika dihubungkan dengan track record beliau baik dalam penyebaran Islam dan perlawanan kolonialisme akan memunculkan indikasi vernakularisasi dan penumbuhan anti-kolonialisme. Dengan itu, penulis memiliki beberapa pertanyaan untuk ditindak lanjuti; bagaimana pemikiran Kiai Shaleh Darat mengenai salat? Bagaimana dinamika pemikiran beliau dalam memaknai salat? Dalam menjawab keduanya, penulis akan dibantu oleh teori Hermeneutika Filosofis.
\end{abstract}

Kata Kunci: Salat, Kiai Shaleh Darat, Hermeneutika Filosofis, Faị̣ al-Raḥmān,Lațāif al-Ṭahāra. 


\section{A. Pendahuluan}

Kiai Shaleh Darat adalah seorang ulama sekaligus pejuang kepercayaan dari Pangeran Diponogoro bersama dua rekannya yaitu Kiai Murtadha dan Kiai Syada' di Semarang. ${ }^{1}$ Nama Kiai Shaleh Darat memang sudah terkenal di tanah Jawa sebagai ulama yang masyhur di zamannya. Kiai Shaleh Darat merupakan salah satu ulama yang cukup aktif dalam menulis karya tulis. Terdapat kurang lebih 14 kitab karangan beliau², di antaranya yaitu Kitab Faị̣ al-Rahmān Fi Tarjamah Tafsìr Kalām Malik al-Dayyān (selanjutnya disebut Faị̣ alRahmmān) dan Latāif al-Ṭahārat wa Asrār al-Sholāh Fī Kaifiyat Sholāt al-Ābidin wa al-Ärifīn (selanjutnya disebut Lațāif al-Tahārat). ${ }^{3}$ Selain itu, beliau satu-satunya ulama, akhir abad 19 yang menulis karyakarya keislamannya dengan menggunakan bahasa Jawa. ${ }^{4}$

Dari dua kitab di atas, salah satu tema yang menarik untuk dikaji adalah salat. Seperti contoh ketika ia menafsirkan ayat:

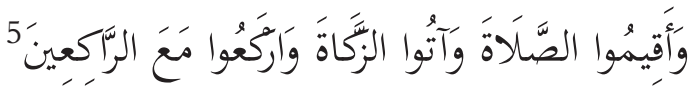

Dan dirikanlah salat, tunaikanlah zakat dan rukuklah bersama orang yang rukuk.

Menurut Kiai Shaleh Darat, salat adalah momen dimana seorang hamba berinteraksi dengan Tuhannya. Di samping itu, salat juga merupakan sebuah proses bagi seorang hamba menuju kebenaran dan mencapai maqam musyāhadah. ${ }^{6}$

1 A. Aziz Masyhuri, 99 Kiai Kharismatik Indonesia, Biografi, Perjuangan, Ajaran dan DoaDoa Utama yang Diwariskan (Yogyakarta: Kutub, 2008), hlm. 86.

214 kitab tersebut, di antaranya: Majmū' al-Syarī'at, Munjiyat Metik Saking Ihyya 'ulūm al-Dīn al-Ghazali, Lathāif al-Ṭahārat wa Asrār al-Sholāh, Manāsik al-Hajj wa al- ‘umrah, Matn al-Hikām, Sabīl al-'Abid Terjemah Jauhāru al-Tauhid Karya Ibrahim Laqqani, Faș alatan, Minhāj al-Atqiya Fī Syarh Ma'rifah al-Atqiya ila Tharīq al-Aulia, al-Musyrid alWajiz Fī 'ilm Alquran al- 'Aziz, Syarh Barzanji, Faidh al-Rahmān, Kitab al-Mahabbah wa al-Mawaddah, Kitab Manāsik Kaifiyat al-Ṣalat al-Musāfirin dan Kitab Hadis al-Mi'raj.

3 Imam Musbikin, Mutiara Alquran... hlm. 200.

4 Imam Musbikin, Mutiara Alquran (Madiun: Jaya Star Nine, 2014), hlm. 199.

5 QS. Al-Baqarah [2] : 43

6 Shaleh Darat, Lathāif al-Ṭahārat wa Asrār al-Sholāh Fī Kaifiyat Sholāt al-Ābidin wa al-Arifinn(Semarang: Toha Putera), hlm. 34. 
Lebih jauh dalam kitab Asrār al-Sholāh, Kiai Shaleh Darat menjelaskan sangat detail perihal salat dan bagaimana tata cara salat yang benar. Sehingga menurut beliau jika seseorang sudah melakukan itu, dia termasuk dalam kategori khairu al-bariyyah (sebaik-baik manusia). ${ }^{7}$ Sebaliknya, jika seseorang tersebut tidak melakukan atau melaksanakan salat, maka menurut Kiai Shaleh Darat dia termasuk dalam kategori syarru al-bariyyah (seburuk-buruk manusia). Bahkan seseorang tersebut dapat termasuk dalam kategori najis. Beliau mendasarkannya pada ayat Alquran, innamā al-musyrikūn najas ${ }^{8}$. Jika sudah dihukumi dengan najis, maka segala amal perbuatannya tidak sah. Baik itu wudu ataupun salat. Karena syarat dari ibadah tersebut harus suci lahir dan batin. ${ }^{9}$

Dari keterangan di atas, maka penulis merasa perlu untuk mengkaji konstruksi pemikiran Kiai Shaleh Darat mengenai salat. Bagaimana beliau menafsirkan ayat-ayat tentang salat dengan demikian, dan faktor apa yang melatarbelakanginya. Adakah determinasi-determinasi dari luar yang mempengaruhi pemikiran Kiai Shaleh Darat. Menilik beliau yang menjadi figur sentral di zamannya.

Penelitian ini menemui relevansinya dengan munculnya gagasan Islam Nusantara yang akhir-akhir ini menjadi diskurus yang ramai dibincangkan. Penelitian terhadap warisan literatur-literatur ulama Nusantara, baik dalam bidang ilmu tafsir maupun ilmu-ilmulainnya yang merupakan bentuk apresiasi dan usaha untuk melestarikan tradisi intelektual Nusantara.

Untuk membantu menjawab kegelisahan akademik di atas, maka penulis memilih menggunakan teori hermeneutika-filosofis. Hermeneutika filosofis merupakan salah satu jenis dari hermeneutika. ${ }^{10}$

7 Shaleh Darat, Lathāif al-Ṭahārat wa Asrār al-Sholāh...hlm. 43.

8 QS. Al-Taubah [9] : 28

9 Soleh Darat, Lathāif al-Ṭahārat wa Asrār al-Sholāh... hlm. 44.

10 Yang pertama adalah hermeneutical theory yang berisi aturan metodologis untuk sampai kepada pemahaman yang diinginkan pengarang (author), dan hermeneutical philosophy yang lebih mencermati dimensi filosofis-fenomonolgis pemahaman. Dan yang terakhir adalah hermeneutika kritis.Fahruddin Faiz, Hermeneutika Alquran: Tema- 
Hermeneutika jenis ini melangkah lebih jauh ke dalam dataran filosofis, sehingga lebih dikenal sebagai hermeneutika filosofis. Hermeneutika jenis ini lebih memfokuskan dan lebih jauh mengupas seperti apa kondisi manusia yang memahami itu, baik dalam aspek psikologisnya, sosiologisnya, historisnya dan lain sebagainya termasuk dalam aspek filosofis yang mendalam seperti kajian terhadap pemahaman dan penafsiran pra-syarat eksistensial manusia. Hal ini secara umum dilakukan untuk dua tujuan: Pertama, meletakkan hasil pemahaman yang dimaksud dalam porsi dan proporsi yang sesuai. Kedua, untuk melakukan suat u produksi makna baru dari pemahaman terdahulu tersebut dalam bentuk kontekstualisasi. ${ }^{11}$ Jika teori ini diterapkan dalam penelitian ini, ia diharapkan akan membantu dalam menemukan jawaban dari rumusan masalah di atas. Selain itu, teori ini diharapkan dapat menunjukkan posisi dari Kiai Shaleh Darat dalam konteks kehidupan beliau saat itu.

Dalam membahas Kiai Shaleh Darat dengan menggunakan teori hermeneutik filosofis, penulis juga akan mendiskusikan periode penafsiran beliau, historical setting, kapan-dimana dan bagaimana Kiai Shaleh Darat menjalani hidup serta menulis karya-karya beliau. Dengan itu, teori ini dapat menuntun pada apakah pemikiran Kiai Shaleh Darat terpengaruh oleh atau terlepas dari guru dan lingkungan.

Dalam pemaparan berikut, penulis menggunakan metode deskriptif-analisis; menjelaskan bagaimana penafsiran Kiai Shaleh Darat tentang salat, kemudian menganalisnya secara kritis, sehingga dapat diketahui konstruksi utuh penafsiran beliau. Di sisi lain, di saat yang sama, pendekatan yang digunakan dalam penelitian ini adalah pendekatan hermeneutis. ${ }^{12}$ Tujuan penggunaan pendekatan ini adalah

Tema Kontroversial... hlm. 4-5.

11 Fahruddin Faiz, Hermeneutika Alquran: Tema-Tema Kontroversial...hlm. 9.

12 Secara terminologis, menurut Zygmunt Bauman, hermeneutik adalah upaya untuk menjelaskan dan menelusuri pesan dan pengertian dasar dari sebuah ucapan atau tulisan yang tidak jelas, kabur remang-remang dan kontradiktif yang menimbulkan kebingungan bagi pendengar at au pembaca. Yang menjadi fokus dari hermeneutika adalah pemahaman dengan menimbang konteks yang objek yang dipahami dan penelusuran terhadap apa 
untuk memahami bagaimana sebenarnya konstruksi penafsiran Kiai Shaleh Darat tentang salat serta variasi penafsiran dalam kedua kitab tersebut.

\section{B. Biografi dan Seputar Dua Karyanya}

Nama lengkap beliau adalah Muhammad Shaleh Ibn Umar alSamarani, atau lebih dikenal dengan sebutan Kiai Shaleh Darat. Beliau adalah putra dari Kiai Umar, salah seorang prajurit Pangeran Diponogoro dalam perang Jawa (18251830-) melawan kolonial Belanda. Beliau lahir di Desa Kedung Jumbleng, Kecamatan Mayong, Kabupaten Jepara, Jawa Tengah sekitar tahun 1820 M. ${ }^{13}$ Ada juga yang menyebutkan bahwa beliau lahir di desa lain, namun informasi tentang tempat kelahirannya di Desa Kedung Jumbleng lebih kuat daripada tempat yang lain. Informasi ini diterima dari Kiai Fahr alRazi, Kajen, Margoyoso, Pati yang mendapat informasi dari Kiai Abdullah yang berasal dari daerah yang sama dengan Kiai Shaleh Darat, Kedung Jumbleng. Kiai Shaleh Darat wafat pada Jum'at Legi tanggal 28 Ramadan 1321 H/18 Desember 1903 M dan dimakamkan di pemakaman umum Bergota Semarang. Karena Kiai Shaleh Darat termasuk ulama yang masyhur pada zamannya, makamnya sering dikunjungi para peziarah dan peringatan haul beliau pun dihadiri banyak orang. ${ }^{14}$

Nama "Darat" yang dinisbahkan pada nama Kiai Shaleh adalah nama daerah di mana beliau berasal. Sejarah penamaan daerah tersebut dengan 'Darat' berawal pada abad 19 ketika kota Semarang memiliki pelabuhan yang penting dalam dunia dagang. Di antara yang berlabuh di pelabuhan itu adalah orang-orang Arab, Persia, India, Tionghoa dan lain sebagainya, termasuk orang Eropa yang

saja yang mempengaruhi sebuah penafsiran sehingga menghasilkan variasi pemahaman.

Fahruddin Faiz, Hermeneutika Alquran: Tema-Tema Kontroversial... hlm. 5-6.

13 Ghazali Munir, Warisan Intelektual Islam Jawa (Semarang: Walisongo Press, 2008), hlm. 33 .

14 Ghazali Munir, Warisan Intelektual Islam Jawa...hlm. 33. 
tujuannya untuk berdagang. Para pedagang ini berlabuh di daerah Ngeboom, sekarang dikenal dengan Boom Lama. Daerah ini semakin ramai karena terus meningkatnya jumlah pendatang baru dari berbagai daerah yang mendarat di daerah tersebut. Tersebutlah daerah tersebut dengan nama Darat atau Ndarat sampai sekarang. ${ }^{15}$

Kiai Shaleh Darat memiliki andil yang cukup besar dalam usaha penyebaran Islam di tanah Jawa, khususnya di Semarang. Hal ini terbukti bukan hanya dari banyaknya karya yang telah beliau tulis, tetapi juga karena keahlian beliau dalam menyampaikan pesan-pesan agama melalui ceramahnya, bukan hanya di kalangan orang awam, namun juga di kalangan bangsawan. ${ }^{16}$

Perjalanan awal pendidikan beliau adalah belajar dari ayahnya sendiri. Pada masa itu, pelajaran berkisar pada pemahaman ilmu Alquran dan fikih dimulai dengan cara membaca surah-surah pendek dalam juz 'amma, serta pelajaran tentang peraturan dan tata cara salat, wudu dan beberapa doa serta ilmu tajwid yang bermanfaat untuk melafalkan ayat-ayat suci secara benar. ${ }^{17}$ Setelah itu beliau melanjutkan pelajaran agama ke beberapa ulama atau kiai terkenal pada masanya baik di Jawa, khususnya di daerah Pati, Kudus, dan Semarang, maupun di Saudi Arabia, khususnya di Haramain, Mekah dan Madinah. Dari beberapa ulama tersebut beliau mendapatkan ijazah-yang nantinya menyambungkan sanad (jalur) keilmuan beliau pada tokoh-tokoh besar pada zamannya.

Di antara guru-guru beliau adalah; K.H.M. Syahid, Waturoyo, Kajen, Margoyoso, Pati, cucu Kiai Ahmad Mutamakkin ${ }^{18}$ yang hidup

15 Ghazali Munir, Warisan Intelektual Islam Jawa... hlm.5.

16 Abdul Mustaqim, Epistemologi Khazanah Tafsir Jawa, Ringkasan Riset,Yogyakarta, 2015, tidak Dipublikasikan, hlm. 17-18.

17 Karel A. Steenbrink, Pesantren Madrasah Sekolah Pendidikan Islam dalam Kurun Modern(Jakarta: LP3ES, 1986), hlm. 10 dalam Ghazali Munir, Warisan Intelektual Islam Jawa...hlm. 8.

18 Masih menjadi perdebatan mengenai biografi dari Kiai Mutamakkin. Ada pendapat yang mengatakan bahwa beliau masih keturunan dari Raden Patah yang berasal dari Sultan Trenggono, hal ini dilihat dari garis keturunan sang ayah. Jika dari garis ibu, beliau merupakan keturunan dari Sayyid Ali Bejagung Tuban, Jawa Timur. Sayyid ini memiliki 
pada masa Pakubuwono II (17271749-), kepada beliau Kiai Shaleh Darat mempelajari beberapa kitab, seperti: Fath al-Qarīb, Fath alMu'īn, Minhāj al-Qawìm, Syarh al-Khatīb dan Fath al-Wahhāb; K.H.R. Muhammad Shaleh ibn Asnawi, tokoh sufi di Kudus, kepada beliau Kiai Shaleh belajar kitab Tafsī Jalālayn, karya al-Suyuti dan al-Mahalli; K. Ishaq, Damaran, Semarang, Kiai Shaleh belajar kepada beliau tentang Naḥw dan Sarf serta Fatḥ al-Wahhāb; K. Abu Abdullah Muhammad al-Hadi ibn Ba'uni, mufti Semarang, kepada beliau Kiai Shaleh belajar ilmu falak; Sayyid Syaikh ibn Ahmad Bafaqih Ba'alawi Semarang, kepada beliau Kiai Shaleh belajar Jauhara al-Tauhid karya Ibrahim al-Laqani dan Minhāj al-Ābidin karya al-Ghazali; Syaikh Abdu al-Ghani Bima Semarang, kepada beliau Kiai Shaleh belajar Sittin Mas'ila; ${ }^{19}$ Haji Muhammad Irsyad, Lowano, Begelen, Purworejo, kepada beliau Kiai Shaleh belajar tentang arti penting ilmu pengetahuan dan mauizah, yang kemudian beliau ungkapkan dalam bentuk nazam. ${ }^{20}$

Pada abad 17 sampai 19 M, Mekah dan Madinah menjadi sumber keilmuan Islam. Dalam perjalanannya, seluruh umat Islam di Dunia yang menuntut ilmu di Mekah dan Madinah mempunyai orientasi yang berbeda. Ada yang menunt ut ilmu di kota tersebut karena pada awalnya melakukan ibadah haji. Ada juga yang murni untuk menuntut ilmu di sana dan menetap untuk beberapa waktu sesuai dengan perjalanan dalam menuntut ilmu. ${ }^{21}$ Termasuk dalam golongan

putra yang bernama Raden Tanu. Dan raden Tanu ini memiliki seorang istri yang menjadi ibunda daripada Kiai Mutamakkin. Beliau adalah ulama sohor yang terkenal dengan kealimannya, bahkan ada yang berpendapat bahwa beliau adalah waliyullah. Beliau telah mengislamkan masyarakat Kajen, serta menjadi inspirasi berkembangnya Islam dengan cepat di daerah Kajen; dapat dilihat pada, Zainul Milal Bizawie, Perlawanan Kultural Agama Rakyat, (Yogyakarta: Samha dan Jakarta: Yayasan Keris, 2002), hlm. 104.

19 Abu al-Abbas Ahmad al-Misri, Sittin al-Ma'ilahdalam Ghazali Munir, Warisan Intelektual Islam Jawa...hlm. 37.

20 Muhammad Shaleh Darat, Sabil al-Abid(Semarang: Toha Putera, t.th), hlm. 37.

21 Azyumardi Azra, Jaringan Ulama Timur Tengah dan Kepulauan Nusantara Abad XVII dan XVIII(Jakarta: Kencana, 2013), hlm. xi. 
yang terakhir ini adalah ulama-ulama dari Asia, khususnya Indonesia.

Kiai Shaleh Darat pun menimba ilmu di Mekah. Belum puas dalam menuntut ilmu di tanah air, sekitar abad ke-19 M, Kiai Shaleh Darat diajak oleh ayahnya untuk singgah ke berbagai daerah, sampai ke Mekah dan Madinah. ${ }^{22}$ Pada saat menuntut ilmu di Haramain, beliau menetap di sana. Pada masa tersebut, ayah beliau wafat di Mekah, namun beliau masih menetap di sana beberapa tahun untuk melanjutkan pengembaraan ilmunya. ${ }^{23}$

Di antara guru-guru beliau saat itu adalah; Syaikh Muhammad alMuqri al-Misri al-Makki, kepada beliau Kiai Shaleh belajar ilmu 'aqāid dengan kitab Umm al-Barāhin karya Muhammad al-Sanusi; Syaikh Muhammad Sulaiman Hasb Allah, seorang pengajar di Masjid alHaram dan Masjid Nabawi, kepada beliau Kiai Shaleh belajar Syarh al-Khatīb, Fatḥ al-Wahhāb dan Alfiyyah ibn Mālik dan Syarh-nya, serta dari beliau Kiai Shaleh mendapat ijazah tentang kitab-kitab tersebut; Sayyid Muhammad ibn Zaini Dahlan, seorang mufti Syafi'iyyah di Mekah, kepada beliau Kiai Shaleh belajar Ihyā' 'Ulūm al-Dīn karya al-Ghazali, dari beliau juga Kiai Shaleh mendapat ijazah; Al-'Allamah Ahmad al-Nahrawi al-Misri al-Makki, ${ }^{24}$ kepada beliau Kiai Shaleh belajar kitab al-Hikam karya Ahmad ibn 'Ata' Allah; Sayyid Muhammad Salih al-Zawami al-Makki adalah seorang guru pengajar di Masjid al-Haram, kepada beliau Kiai Shaleh belajar kitab Ihyā' 'Ulüm al-Dīn juz 1 dan II; Kiai Zahid atau Zaid, kepada beliau Kiai Shaleh belajar Fatḥ al-Wahhāb beserta ijazahnya; Syaikh 'Umar al-Syami, kepada beliau Kiai Shaleh belajar Fatḥ al-Wahhāb. Syaikh al-Sanbulawi al-Misri, Kiai Shaleh Darat belajar terhadanya Syarh al-Tahrïr karya dari Zakariya al-Ansari; Syaikh Jamal, seorang Mufti Hanafi di Mekah,kepada beliau Kiai Shaleh belajar tafsir Alquran. ${ }^{25}$

22 Ghazali Munir, Warisan Intelektual Islam Jawa...hlm. 37.

23 Aziz Masyhuri, 99 Kiai Kharismatik Indonesia, Biografi, Perjuangan, Ajaran, dan Doa-

Doa Utama yang Diwariskan(Yogyakarta: Kutub, 2008), hlm. 67.

24 Muhammad Shaleh Darat,Majmu'at al-Syari 'at(Semarang: Toha Putera,t.th), hlm. 34. 25 Muhammad Shaleh Darat, al-Mursyìd al-Wajiz... hlm. 97. 
Sekembalinya dari Mekah, Kiai Shaleh Darat terlebih dahulu singgah di Singapura beberapa saat dan kemudian baru kembali ke Indonesia. Setelah berada di Indonesia, Kiai Shaleh Darat mulai mengajar di Pondok Pesantren Salatiang yang terletak di Desa Maron, Kecamatan Loana, Purworejo. Pesantren ini didirikan sekitar abad ke-18 oleh tiga orang sufi, yaitu Kiai Achmad Alim, Kiai Muhammad Alim dan Kiai Zain al-Amin. Dalam perkembangannya, pesantren ini dipercayakan kepada Kiai Zain al-Alim. Sementara Kiai Achmad Alim mengasuh pesantren yang bernama al-Imam, di Desa Bulus, Kecamatan Gebang. Adapun Kiai Muhammad Alim mengasuh pesantren al-Anwar, di Desa Maron. Jadi, Kiai Shaleh Darat membantu Kiai Zain al-Alim sebagai pengajar di Pesantren Salatiang. ${ }^{26}$

Pesantren Salatiang ini lebih fokus pada bidang penghafalan Alquran, di samping juga mengajarkan kitab-kitab kuning. Besar kemungkinan bahwa di sana Kiai Shaleh Darat diperbantukan untuk mengajarkan kitab-kitab kuning, seperti fikih, tafsir, nahwu, dan sharaf kepada santri yang sedang menghafal Alquran. ${ }^{27}$

Tidak jelas berapa lama Kiai Shaleh menjadi guru pembantu di pesantren Salatiang. Sejarah hanya mencatat bahwa, sekitar tahun 1870-an Kiai Shaleh Darat mendirikan pesantren baru di Darat, Semarang. Hitungan ini berdasarkan pada kitabnya, Matn al-Hikam, yang selesai ditulis dengan bahasa Arab pegon pada tahun 1289 H/1871 M. ${ }^{28}$ Sebab, alasan pindahnya Kiai Shaleh Darat ke Semarang ialah karena beliau dijodohkan dengan putri dan dijadikan sebagai menantu oleh Kiai Murtada. Kiai Murtada adalah teman seperjuangan dari Kiai Umar (ayah dari Kiai Shaleh). Sejak saat itulah, Kiai Shaleh Darat menetap di Semarang dan masih menuntut ilmu lagi ke beberapa ulama, serta mendirikan sebuah pondok pesantren yang

26 A. Aziz Masyhuri, 99 Kiai Kharismatik Indonesia Biografi, Perjuangan, Ajaran, dan Doa-Doa Utama yang Diwariskan... hlm. 67.

27 A. Aziz Masyhuri, 99 Kiai Kharismatik Indonesia Biografi, Perjuangan, Ajaran, dan Doa-Doa Utama yang Diwariskan... hlm. 67.

28 Abdurrahman Mas'ud, Intelektual Pesantren Perhelatan Agama dan Tradisi (Yogyakarta: LKIS, 2004), hlm. 138. Lihat juga Muhammad Shaleh ibn Umar as-Samarani,Matn al-H ikam (Semarang:Toha Putera, t.th), hlm. 2. 
semula tidak menggunakan nama. Namun, lambat laun pondok pesantren ini lebih dikenal dengan Pondok Pesantren Darat. Dari namanya yang diketahui, bahwa bangunan itu dibangun oleh seorang kiai yang tinggal di kampung Darat, yaitu Muhammad Shaleh pada pertengahan abad ke $19 .^{29}$

Selama mengasuh pondok pesantren, Kiai Shaleh Darat dikenal kurang begitu memperhatikan kelembagaan pesantren. Karena faktor inilah, Pesantren Darat menghilang tanpa bekas sepeninggal Kiai Shaleh Darat, pada tahun 1903 M. Ada juga yang menjelaskan bahwa pesantren Darat yang didirikan oleh Kiai Shaleh Darat bukan arti pesantren sesungguhnya, melainkan hanya sebuah majlis pengajian dengan kajian bermutu yang diikuti oleh para santri kalong. ${ }^{30}$

Terlepas dari perdebatan apakah pesantren ini bermakna pesantren yang sama dengan pada umumnya pesantren atau tidak, pada intinya pesantren ini telah melahirkan tokoh-tokoh Islam yang handal di tingkat nasional, dan bahkan yang bertaraf "internasional". Di antaranya yaitu: K.H. Mahfuz ibn Abdullah ibn Abdul Manan, (w. 1338 H/1919 M), keturunan ke-7 dari Raja Brawijaya V, yang terkenal dengan sebutan Syaikh Mahfuz al-Tirmisi, seorang yang ahli dalam ilmu hadis. K.H. Ahmad Dahlan (18681923- M), seorang tokoh pendiri Muhammadiyah. K.H. Hasyim Asy'ari (18711947- M), menjadi pendiri Pondok Pesantren di Tebuireng, Jombang, yang sekaligus sebagai pendiri Nahdlatul Ulama. K.H.R. Dahlan dari Tremas (w. 13291919/ M), yang kemudian menjadi seorang menantu dari Kiai Shaleh Darat. ${ }^{31}$ K. Amir (w. 1357 H/1939 M) dari Brebes. Pendiri pondok pesantren di Simbang Kulon. K. Idris (w. 1341 H/1927 M) dari Solo. Ia lah yang menghidupkan kembali Pondok Pesantren Jamsaren yang didirikan oleh Kiai Jamsari. ${ }^{32}$ K.H. Abdul Hamid (w. 1348 H/1930 M) dari Kendal. K.H. Sya'ban ibn Hasan (w. 1364 H/1946 M)

29 Ghazali Munir, Warisan Intelektual Islam Jawa... hlm. 55.

30 A. Aziz Masyhuri, 99 Kiai Kharismatik Indonesia, Biografi, Perjuangan, Ajaran, dan

Doa-Doa Utama yang Diwariskan...hlm. 75.

31 Ghazali Munir, Warisan Intelektual Islam Jawa... hlm. 56.

32 Ghazali Munir, Warisan Intelektual Islam Jawa... hlm. 56. 
dari Semarang. K.H. Tahir dari Semarang. K.H. Sahli seorang Kiai di Kauman Semarang. K.H. Dimyati (w. 1934) yang merupakan adik dari Kiai Mahfuz Tremas. K.H. Khalil (w. 1940) dari Rembang. K.H. Munawwir (w. 1940) pendiri Pondok Pesantren al-Munawwir Krapyak Yogyakarta. Kiai Yasin dari Rembang. K.H. Ridwan ibn Mujahid (w. 1950) dari Semarang. Bapak Ali Berkah, Kiai Penghulu Tafsir Anom, ${ }^{33}$ K.H. Yasir dari Bareng Kudus. K.H.R. Asnawi (w. 1959) dari Kudus. K.H. Muzakir dari Demak. K.H. Siraj dari Payeman Magelang. K.H. Anwar Mujahid dari Semarang. K.H. Abdu Samad dari Solo. K.H. Dalhar pendiri Pondok Pesantren Watucongol Muntilan. K.H. Harun, K.H. Sajad. ${ }^{34}$ R.A. Kartini, seorang tokoh perempuan di Indonesia. ${ }^{35}$ Beberapa nama tersebut adalah santri dari Kiai Shaleh Darat yang datang dari berbagai daerah, dan kembali ke daerah asal dan menjadi tokoh di masing-masing tempat asalnya.

Pondok pesantren Darat ini berakhir sampai dengan wafatnya Kiai Shaleh Darat pada hari Jum'at Legi tanggal 28 Ramadan 1321 H/18 Desember 1903 M yang pada saat itu jumlah santrinya lebih dari seratus. Kemudian, sebagai santri senior dan seorang guru ngajar, Kiai Idris memboyong beberapa santri ke Solo untuk menghidupkan kembali Pondok Pesantren Jamsaren pada tahun 1904. ${ }^{36}$

Beliau dapat dinilai sebagai ulama yang produktif secara keilmuan, terbukti banyak kitab-kitab yang ditulisnya dengan menggunakan bahasa pegon. Hingga saat ini, karya-karyanya masih dibaca di pondok-pondok pesantren di Jawa.

Di antara karya-karya dari Kiai Shaleh Darat ialah Majmū' al-Syarī'at, Munjiyat Metik Saking Ihya 'ulüm al-Dīn al-Ghazali, Lathāif al-Ṭahārat wa Asrār al-Sholāh, Manāsik al-Hajj wa al- 'umrah, Matn al-Hikām, Sabīl al-'Abid Terjemah Jauhāru al-Tauhid Karya

33 Kanjeng Raden Penghulu Tafsir Anom adalah seorang ulama bangsawan sebagai abdi dalem Keraton Surakarta. Beliau memangku jabatan sebagai penghulu (qadli) ketika Sri Susuhunan Paku Buwana IX (1861-1893) berkuasa.

34 Ghazali Munir, Warisan Intelektual Islam Jawa... hlm. 57.

35 Abdul Mustaqim, Epistemologi Khazanah Tafsir Jawa, hlm. 17.

36 Ghazali Munir, Warisan Intelektual Islam Jawa... hlm. 58-59. 
Ibrahim Laqqani, Faṣalatan, Minhāj al-Atqiya Fī Syarh Ma'rifah al-Atqiya ila Thariq al-Aulia, al-Musyrid al-Wajiz Fỉilm Alquran al-'Aziz, Syarh Barzanji, Faidh al-Rahmān, Kitab al-Mahabbah wa al-Mawaddah, Kitab Manāsik Kaifiyat al-Șalat al-Musāfirīn dan Kitab Hadis al-Mi'raj.

\section{Sejarah Penafsiran dan Penerjemahan Alquran di Indonesia}

Penerjemahan dan penafsiran Alquran di Indonesia sudah ada sejak masuk dan berkembangnya Islam. Meskipun pada praktiknya, dalam menerjemahkan dan menafsirkan Alquran seseorang tidak harus membuat sebuah kitab terlebih dahulu. Mereka hanya menyampaikan pesan-pesan yang terkandung dalam Alquran dengan bahasa yang dapat dimengerti oleh muridnya. Seperti yang dikatakan oleh Indal Abrar, bahwa pengajaran Alquran masih bercampur dengan ajaranajaran tauhid, fikih, tasawuf, dan lain-lain, yang disajikan secara praktis dalam bentuk amaliah sehari-hari. ${ }^{37}$

Penulisan tafsir Alquran di Nusantara sudah terjadi sejak abad ke-16. Buktinya yaitu ditemukannya kitab Tafsir Surah al-Kahfi yang ditulis pada masa itu, akan tetapi belum diketahui siapa penulis kitab tersebut. ${ }^{38}$ Naskahnya dibawa oleh Erpinus (w.1624) pada awal abad ke-17 M dari Aceh menuju Belanda, dan sekarang menjadi koleksi Cambridge University Library. Naskah ini diduga ditulis pada masa awal pemerintahan Sultan Iskandar Muda (16071636-), yang jabatan mufti saat itu dipegang oleh Syams al-Din al-Sumatrani, atau bahkan sebelumnya, yaitu Sultan Ala' al-Din Ri'ayat Syah Sayyid alMukammil (15371604-), yang saat itu mufti kesultanannya dipegang oleh Hamzah Fansuri. ${ }^{39}$ Ada dugaan bahwa naskah ini ditulis oleh

37 Indal Abror, "Potret Kronologis Tafsir Indonesia", Jurnal Esensia, Vol. 3, No. 2, Juli 2002, hlm. 191 dalamM. Nurdin Zuhdi, Pasaraya Tafsir Indonesia(Yogyakarta:Kaukaba Dipantara, 2014), hlm.61.

38 M. Nurdin Zuhdi, Pasaraya Tafsir Indonesia... hlm.61.

39 Peter Riidle, Islam and the Malay-Indonesian World, Transmission and Responses, hlm. 161-5 dalam Islah Gusmian, "Bahasa dan Aksara Tafsir Alquran di Indonesia”, Jurnal 
Syamsuddin al-Sumatrani atau Hamzah Fansuri, yang pada masanya, ia dikenal sebagai syaikh Tarekat Qadariyah. Misal karya dari kedua tokoh tersebut tidak dibakar oleh Nurudin al-Raniri, tentu dugaan ini akan menemukan kejelasannya. Akan tetapi, satu hal yang pasti adalah tafsir ini berisi tentang kebijaksanaan negara pada saat itu yang berkaitan dengan masalah-masalah keagamaan dan cenderung berpaham sufisme. Karya sejenis ini tumbuh subur di era kesultanan sebelum Iskandar Tsani dengan mufti Nurrudin al-Raniri. ${ }^{40}$

Satu abad kemudian, tepatnya pada abad ke-17, terdapat karya tafsir dari Abdur Rauf al-Sinkili (1651693-) dengan judul Tafsir Tarjumān al-Mustafĩd. Ia dikenal sebagai mufasir pertama yang menulis karya tafsir lengkap tiga puluh juz. Dikatakan pertama, karena belum ditemukan adanya karya tafsir sebelumnya yang menulis karya tafsir lengkap tiga puluh juz.

Karya ini pertama terbit di Istanbul (Konstatinopel) pada tahun 1302 H/1884 M. Kemudian, karya ini dicetak ulang berkali-kali di Istanbul, Mekah, Kairo, Bombay, Penang, Singapura, setelah mendapatkan pengakuan dari para ulama Mekah dan Madinah. Karya ini dicetak di Indonesia pada tahun $1984 .{ }^{41}$ Pada abad munculnya Tafsir Tarjumān al-Mustafīd ini, muncul juga literatur tafsir bercorak sufistik yang ditulis di Sampon, Aceh, dengan judul Tasdiq al-Ma'ārif, namun penulis dari kitab ini tidak dapat ditemukan. Tafsir ini merupakan tafsir sufistik dan ditulis untuk membela prinsip-prinsip ajaran sufi. ${ }^{42}$

Karya-karya pada abad ke-17 di atas sudah menggunakan aksara pegon. Kemungkinan ini seolah mendapatkan titik terang, ketika dalam tulisan A.H. John mengatakan bahwa, pada akhir abad ke-16

Tsaqofah, Vol. 6, No. 1, April 2010, hlm. 5.

40 Peter Riddle, Islam and the Malay-Indonesian World, Transmission and Responses, $\mathrm{h}$. 150, dalam Islah Gusmian, "Bahasa dan Aksara Tafsir Alquran di Indonesia, Jurnal Tsaqofah, Vol. 6, No. 1, April 2010, h. 5.

41 Salman Harun, Mutiara Alquran, (Jakarta: Logos, 1999), h. 198, dalamM. Nurdin Zuhdi, Pasaraya Tafsir Indonesia, h.61-62.

42 A. John, "Islam di Dunia Melayu: Sebuah Survei Penyeledikan dengan Beberapa Referensi Kepada Tafsir Alquran," dalam Azyumardi Azra, (peny.), Perspectif Islam di Asia Tenggara, (Jakarta: Yayasan Obor Indonesia, t.th), hlm. 126, 228, dalam M. Nurdin Zuhdi, Pasaraya Tafsir Indonesia... hlm. 63-64. 
terjadi pembahasalokalan Islam ke berbagai wilayah Nusantara. Salah satu bentuknya adalah penggunaan aksara (script) Arab akan tetapi dengan bahasa Melayu-Jawi, yang kemudian disebut dengan aksara pegon.

Dipakainya bahasa Melayu berhuruf Jawi, kemudian menjadi alat yang umum dipakai untuk komunikasi antar negara, hubungan pemerintahan dan perdagangan pada saat itu. ${ }^{43}$ Untuk masyarakat yang tidak terlibat di dalam ketiga hal tersebut, maka kemungkinan tidak bisa memahami aksara tersebut, yang mereka pahami adalah bahasa-bahasa asli daerahnya. Oleh sebab itu, karya tafsir yang menggunakan bahasa Melayu-Jawi tidak bisa dikonsumsi oleh khalayak umum, hanya orang-orang yang memahami bahasa MelayuJawi saja yang dapat membaca.

Dengan fakta tersebut, bahasa Melayu-Jawi kurang populer, sehingga karya tafsir yang menggunakan bahasa tersebut pun tidak begitu populer di masyarakat. Ditambah, hegemoni kolonialisme penjajah semakin memasuki wilayah-wilayah politik keraton, perdagangan, dan pemerintahan. Selagi penjajah masih menguasai tanah air, ini adalah kesempatan yang gemilang bagi penjajah untuk mengenalkan bahasa Roman. Bagaimanapun juga, romanisasi bisa dikatakan tidak begitu berpengaruh pada proses penulisan tafsir di beberapa daerah mengingat masih banyak karya yang lahir dengan menggunakan bahasa Melayu-Jawi atau dengan menggunakan tulisan pegon.

Pada abad ke-19, muncul karya tafsir yang berjudul Kitab Farā'idu al-Qur'ān. Tafsir ini menggunakan bahasa Melayu-Jawi. Sebagaimana naskah Tafsïr Surah al-Kahfi, penulisnya tidak dapat diketahui. Kitab tafsir ini ditulis dalam bentuk yang sangat sederhana, dan seperti artikel tafsir, sebab hanya terdiri dari dua halaman dengan huruf kecil dan spasi rangkap. ${ }^{44}$ Literatur kitab ini menafsirkan dua ayat dari Surah al-Nisā, yaitu ayat 11 dan 12 yang berbicara mengenai warisan.

43 Islah Gusmian, "Bahasa dan Aksara Tafsir Alquran di Indonesia”... hlm. 6. 44 M. Nurdin Zuhdi, Pasaraya Tafsir Indonesia... hlm. 64. 
Pada abad ini juga muncul karya tafsir lain, yaitu Tafsìr al-Munīr Ii Ma'alim alTanzīl yang ditulis oleh ulama asli Indonesia bernama Muhammad Nawawi al-Bantani (18131879- M). Walaupun dia merupakan ulama asli Indonesia, akan tetapi tafsir ini ditulis dengan bahasa Arab. Penulisan kitab ini dilakukan di Mekah dan selesai pada hari Rabu, 5 Rabi'ul Akhir $1305 \mathrm{H}^{45}$

Di akhir abad 19, terdapat karya tafsir dengan menggunakan bahasa Jawa yang berjudul Faị al-Rahmān Fī Tarjama Tafsìr Kalām Malik al-Dayyān, karya dari Kiai Shaleh Darat. Kitab ini terdiri dari dua jilid, jilid pertama terdiri dari Surah al-Fatihah sampai Surah al-Baqarah sebanyak 503 halaman, dan jilid yang kedua terdiri dari Surah Ali Imran sampai dengan Surah al-Nisa sebanyak 705 halaman. ${ }^{46}$

Pada awal abad ke-20, romanisasi sudah meranjak ke semua sektor. Pemerintah kolonial Belanda berusaha menjadikan aksara roman menjadi aksara baku di Indonesia. Usaha tersebut dapat dilihat dari adanya suatu sistem legislatif, seperti administrasi, kepegawaian, pendidikan, dan lain-lain, regulasi itu berlaku baik untuk pribumi maupun non-pribumi. ${ }^{47}$ Dengan itu, besar kemungkinan pemakaian aksara roman ini telah merasuki ranah dari penulisan tafsir di Indonesia. Seperti pada awal-awal abad $20 \mathrm{M}$, keragaman penulisan karya tafsir juga sedikit berbeda. Baik dari aksara yang digunakan, maupun konsentrasi tema penafsirannya. Seperti karya dari A. Halim Hassan, Zainal Arifin dan Abdurrahman Haitami, dengan judul Tafsir Alquran al-Karim.

Pada periode ini berkembang juga penafsiran dengan sistematika yang berkonsentrasi pada surah-surah tertentu. Seperti pada penafsiran Surah al-Fatihah, lahir karya tafsir dengan judul Alquranul Karim, Surah al-Fatihah karya dari Muhammad Nur Idris, pada tahun 1955. Setahun kemudian, lahir karya tafsir dengan judul Rahasia Ummul Qur'an atau Surah al-Fatihah karya dari A. Bahry. Ada juga yang

45 M. Nurdin Zuhdi, Pasaraya Tafsir Indonesia... hlm. 64.

46 Misbahus Surur, "Metode dan Corak Tafsir Faidh Ar-Rahman Karya Muhammad Shaleh

Darat As-Samarani",Skripsi IAIN Walisongo Semarang, 2011, hlm. 30.

47 Islah Gusmian, "Bahasa dan Aksara Tafsir Alquran di Indonesia... hlm. 6. 
khusus menafsirkan Surah Yasin. Seperti karya dari A. Hassan dengan judul Tafsir Surah Yasien dengan Keterangan pada tahun 1951, Tafsir al-Quranul Karim karya dari Adnan Yahya Lubis dan terbit pada tahun 1978. Selain itu, pada abad ini juga terdapat beberapa karya tafsir yang khusus menafsirkan juz-juz tertentu, seperti pada Juz Amma. Lahir karya dari H. Abdulkarim Amrullah dengan judul Al-Burhan, Tafsir Juz Amma pada tahun 1922. Kemudian karya dengan judul alHidayah Tafsir Juz Amma oleh Adnan Lubis, pada tahun 1954, ${ }^{48}$ dan masih banyak yang lainnya.

Pada abad ini juga terdapat karya tafsir lengkap 30 juz. Di antaranya karya dari Mahmud Yunus dengan judul Tafsir Alquran alKarim Bahasa Indonesia, yang selesai ditulisnya pada tahun 1938. Kemudian karya dari A. Hassan dengan judul al-Furqan Tafsir Qur'an. Tafsir ini ia tulis berangsur-angsur dan diterbitkan secara berangsurangsur juga, sampai rampung menjadi satu buku pada tahun 1950-an. Selain penulisan tafsir Alquran, pada abad ke-20 ini juga muncul penerjemahan Alquran. Seperti karya Bachtiar Surin yang berjudul Terjemah dan Tafsir Alquran: Huruf Arab dan Latin, pada tahun 1978. ${ }^{49}$

Sampai pada akhir abad ke 20, tepatnya pada dekade 19902000-an muncul beberapa karya tafsir yang sangat beragam dan kreatif. Seperti Konsep Kufr dalam Alquran, Suatu Kajian Teologis dengan Pendekatan Tafsir Tematik, karya dari Harifuddin Cariwu. Kemudian Konsep Perbuatan Manusia Menurut Alquran, Suatu Kajian Tafsir Tematik, karya dari Jalaluddin Rahman, ${ }^{50}$ dan masih banyak karyakarya yang lain.

Keragaman model penafsiran ini menunjukkan bahwa adanya perkembangan pemikiran mufasir dari tahun ke tahun. Beberapa karya tafsir merupakan usaha dalam menjelaskan suatu ayat atau surah yang sering dibaca masyarakat. Seperti penafsiran yang berkonsentrasi pada Surah al-Fatihah. Pemilihan Surah al-Fatihah karena surah ini adalah inti dari Alquran atau sering disebut Ummul Qur'an. Kemudian,

48 Islah Gusmian, Khazanah Tafsir Indonesia (Yogyakarta: LKiS, 2013), hlm. 45-47.

49 Islah Gusmian, Khazanah Tafsir Indonesia hlm. 49.

50 Islah Gusmian, Khazanah Tafsir Indonesia hlm. 63-64. 
penafsiran yang khusus pada Surah Yasien. Alasannya karena surah ini sering dibaca oleh masyarakat pada malam Jum'at, dan alasan lain yang itu pada intinya membaca Surah Yasin. Tren penafsiran di atas semakin berkembang sampai pada abad ke-20. Seperti yang telah dipaparkan di atas.

\section{Brief Review Faiḍ al-Raḥmān dan Kitab Lațaif al-Tahāra}

Kitab tafsir Faị̣ al-Raḥmān ini merupakan kitab tafsir pertama di akhir abad ke-19 yang menggunakan bahasa Jawa. Kitab ini terdiri dari dua jilid, jilid pertama terdiri dari Surah al-Fatihah sampai Surah al-Baqarah sebanyak 503 halaman. Sedangkan jilid yang kedua terdiri dari Surah Ali Imran sampai dengan Surah al-Nisa sebanyak 705 halaman. ${ }^{51}$

Sistematika penulisan kitab tafsir ini diawali menyebutkan nama-nama surah, sekaligus menjelaskan sejarah penurunannya yang kemudian menghasilkan keterangan surah tersebut masuk dalam kategori makkiyah atau madaniyah. Setelah itu, dicantumkan satu ayat yang kemudian diartikannya ke dalam bahasa Jawa. ketika menafsirkan ayat tersebut, Kiai Shaleh Darat menggunakan bahasa Jawa. Penafsiran yang beliau lakukan dalam kitab ini lebih mengarah kepada corak isyāri. Hal ini dapat dilihat dari beberapa penafsiran beliau terhadap suatu ayat yang lebih bernuansa sufi.

Menurut Abdul Mustaqim, nuansa sufi dari kitab tafsir ini dapat dilihat dari judulnya, yaitu Faị̣ al-Raḥmān. Secara bahasa, kata Faị̣ al-Raḥmān berarti limpahan dari Zat Yang Maha Kasih, sebagai isyarat bahwa kandungan tafsir tersebut merupakan limpahan kasih sayang Tuhan yang tercermin dalam uraian-uraian tafsirnya. ${ }^{52}$

Kitab Lațāif al-Tahāra wa Asrar al-Ṡalah selesai ditulis pada tanggal 27 Sya'ban 1307 H. Seperti yang tertera pada judulnya, kitab ini membahas tentang bersuci, rahasia-rahasia dari salat. Kemudian dilanjutkan dengan pembahasan rahasia-rahasia dari berpuasa,

51 Misbahus Surur, "Metode dan Corak Tafsir Faidh Ar-Rahman Karya Muhammad Shaleh Darat As-Samarani",Skripsi IAIN Walisongo Semarang, 2011, hlm. 30.

52 Abdul Mustaqim, Epistemologi Khazanah Tafsir Jawa, hlm. 43. 
keutamaan dari bulan Sya'ban, bulan Asyura dan bulan Rajab. Akan tetapi, pada pembahasan kali ini akan lebih difokuskan pada pembahasan tentang salatnya. Kitab ini berisi 96 halaman diawali dengan mukadimah dari Kiai Shaleh Darat, kemudian masuk pada pembahasan inti dari kitab ini, diawali dengan pembahasan țahāra. Kitab ini ditulis menggunakan bahasa Jawa dengan aksara Arab (pegon). Tidak jauh berbeda dengan kitab-kitab yang lain, tujuannya adalah agar karya-karyanya dapat lebih dimengerti oleh orang-orang awam. Sehingga gagasan-gagasan yang terkandung dari setiap karya tulisnya dapat dipahami oleh masyarakat.

Sumber yang digunakan kitab ini diambil dari beberapa karya ulama-ulama sebelumnya. Seperti karya dari Syaikh al-Nasaburi dalam kitab al-Lathāif, Badāyi ' al-Shanāyi ' fì Aḥkām al-Syāri', ${ }^{53}$ kedua kitab tersebut menjadi rujukannya dalam pembahasan bersuci. Jika dilihat lebih dalam, maka di sana juga terdapat penjelasan-penjelasan yang beliau kutip dari kitab karya al-Ghazali. Akan tetapi Kiai Shaleh Darat tidak secara jelas menunjukkan penjelasan atau pendapat mana yang beliau kutip, beliau hanya mengatakan bahwa dalam pembahasan ini beliau mengutip dari sumber ini. Terlepas dari itu, hal ini menunjukkan bahwa Kiai Shaleh Darat memahami adab dalam kepenulisan, dengan menyantumkan sumber-sumber yang beliau kutip.

\section{E. Konsep Salat Kiai Shaleh Darat}

Salat adalah munajat seseorang dengan TuhanNya. Definisi ini disampaikan melalui penafsirannya pada Surah al-Baqarah ayat 3:

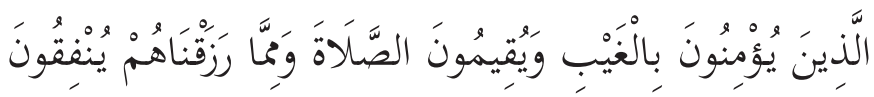

"Solat iku munajate wong mukmin marang pengerane. Podo solato siro kabeh kerono arah iling hudur ono ing ngersane pengeran. Moko kui njenengono solat kelawan ruku' lan sujud sertane adab dzahir lan batin.".54

53 Shaleh Darat, Lathāif al-Thaharah wa Asrar al-Shalah...hlm. 10.

54 Shaleh Darat, Faidh al-Rạ̣mān Fi Tarjamah Tafsīr Kalām Malik al-Dayyān (Semarang:

Toha Putera, tth), hlm. 34. 
Salat adalah keadaan di mana seorang mukmin bermunajat dengan Allah. Salatlah kalian semua dengan mengingat bahwa Allah hadir dalam salat kalian. Oleh sebab itu, dirikanlah salat dengan syarat dan rukun secara lahir maupun batin.

Kegiatan seperti rukuk, sujud dan tasyahud dalam salat merupakan realisasi dari bentuk interaksi seorang hamba kepada Allah, yang mana isinya berkaitan dengan doa, zikir, pengagungan dan bersalawat kepada nabi. Penjelasan ini tidak jauh berbeda dengan al-Ghazali bahwa dalam salat tidak ada sesuatu melainkan bacaan zikir, doa, rukuk, sujud, berdiri, dan duduk. Hakikat salat sesungguhnya adalah keadaan seseorang yang bermunajat kepada Allah. ${ }^{55}$

Dalam mengerjakan suatu ibadah, seseorang harus merasakan kehadiran hati di dalamnya. Dengan menghadirkan hati dia dapat meresapi makna yang terkandung dalam ibadahnya.

Allah Swt. berfirman :

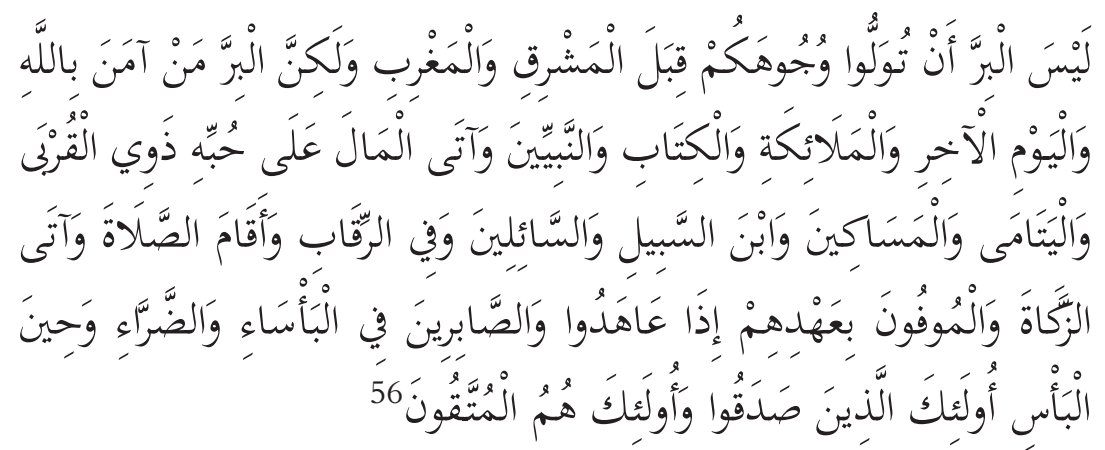

"Bukanlah menghadapkan wajahmu ke arah timur dan barat itu suatu kebajikan, akan tetapi sesungguhnya kebajikan itu ialah beriman kepada Allah, hari kemudian, malaikat-malaikat, kitabkitab, nabi-nabi dan memberikan harta yang dicintainya kepada kerabatnya, anak-anak yatim, orang-orang miskin, musafir (yang memerlukan pertolongan) dan orang-orang yang memintaminta; dan (memerdekakan) hamba sahaya, mendirikan salat,

55 Muhammad al-Ghazali,Rahasia-Rahasia Salat, terj. Muhammad al-Baqir(Bandung:

Karisma, 2003),hlm. 57.

56 QS. Al-Baqarah [2] : 177 
dan menunaikan zakat; dan orang-orang yang menepati janjinya apabila ia berjanji, dan orang-orang yang sabar dalam kesempitan, penderitaan dan dalam peperangan. Mereka itulah orang-orang yang benar (imannya); dan mereka itulah orang-orang yang bertakwa."

Menurut Kiai Shaleh Darat, semua ibadah di atas bukanlah termasuk amal kebajikan jika tidak disertai di dalamnya amal batin. Kata مَشْرِ menunjukkan 'alam arwah' dan kata مَغْرِ menukkan 'alam ajsam'. Jadi ketika seseorang melaksanakan amal kebaikan, haruslah melakukan amal lahir beserta batin. Dan yang dimaksud amal bir secara hakiki adalah menjadikan Allah sebagai satu-satunya yang dia cintai. Realisasinya dengan meniadakan selain Allah di dalam hatinya. Terlebih ketika melakukan sebuah ibadah. ${ }^{57}$

Menghadirkan hati dalam salat juga selalu disampaikan Kiai Shaleh Darat, seperti yang tercantum dalam tafsirnya, bahwa:

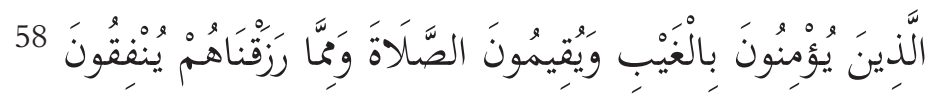

Artine: "rupane wong muttaqin: iku wong kang ngimanaken (percoyo) ing barang kang ghaib (ora ketingal dining moto), lan wong kang podo ngelakoni solat (limang waktu kelawan netepi syarat lan rukune) lan maleh sifate wong muttaqin iku podo nafaqahaken setengah sangking barangkang wes ingsun (Allah) paringaken marang wongiku kabeh kelawan dedalan zakat utowo sodaqah.

Ngimani barangkan samar wujud e kui koyok iman marang dino kiamat, iman neng malaikat, iman neng alam kubur lan alam barzah lan sakpinunggalane. Utawi ngimanaken ing hukume Allah perintah lan cegah ing ndalem tingkahe ghaib sangking menungso. Tegese olehe ngelakoni perintah lan cegah podo ugo ono menungso utowo ora ono." $" 59$

57 Shaleh Darat, Faidh al-Rạ̣mān Fī Tarjamah Tafsīr Kalām Malik al-Dayyān...hlm. 319. 58 QS. Al-Baqarah [2] : 3

59 Shaleh Darat, Hidāyat al-Rahman(Semarang: al-Munur, 1935), hlm. 17. 
Artinya: Yang disebut sebagai orang yang bertakwa adalah orang yang mengimani sesuatu yang ghaib (yang tidak tampak oleh mata lahir), dan orang yang senantiasa melaksanakan salat (5 waktu serta memenuhi syarat dan rukunnya). Juga termasuk sifat orang yang bertakwa adalah dia yang menafakahkan sebagian hartanya melalui zakat atau sedekah. Mengimani sesuatu yang samar wujudnya seperti mengimani adanya hari kiamat, iman terhadap malaikat, iman adanya alam kubur, alam barzah dan sesuatu yang ghaib lainnya. Atau iman terhadap hukum Allah baik perintah atau larangannya meskipun di sana tidak ada manusia lain yang melihatnya. Artinya dia akan tetap melaksanakan perintah Allah dan menjauhi segala laranganNya ada atau tidak ada seseorang lain yang menyaksikannya.

Di ayat lain Allah berfirman:

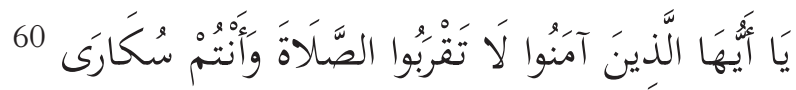

Kiai Shaleh Darat menafsirkan ayat di atas, sebagai berikut:

"Yuqimūn al-Shalāt iku kelawan arep nekani solat limang waktu kelawan adabe solat dhahir utowo yo batine kelawan arep nyukupi syarat rukune, kelawan nekani huquq al-salat, khusyu', tawadhu', hibah, khauf, lan mesti kelawan shuduq lan ikhlas ing ndalem niate. Kerono iku sholat munajat al-mukminin marang pengeran, qāla aqim al-shalāt li dzikr Allah. Podo solato siro kabeh kerono arah iling hudhur ana ing ngersane pengeran. Ojo koyok solate wong mendem, badane ngadek ing ndalem masjid, atine mubengmubeng ing ndalem pasar. Lisane moco fatihah, lisan atine caturan ana ing pasar.Mongko ngunu iku ora yuqīmūn al-shalāt. Balik, ngadekaken solat ora ngadekaken solat, ora."61

Yuqimūn al-Shalāt adalah menegakkan salat 5 waktu, termasuk juga adab dari salat. Baik dari lahir maupun batinnya unt uk memenuhi syarat rukun dari salat. Dalam mendirikan salat, juga harus disertai

60 QS. Al-Nisa' [4] : 43

61 Shaleh Darat, Faidh al-Raḥmān Fỉ Tarjamah Tafsīr Kalām Malik al-Dayyān...hlm. 33. 
dengan hak-haknya (salat), seperti, khusyuk, tawadhu, hibah, khauf, dan yang pasti adalah shuduq serta ikhlas dalam niatnya. Karena salat adalah munajatnya seorang mukmin kepada Tuhannya, qāla aqim al-shalāt li dzikr Allah. Dirikanlah salat karena mengingat (Allah) hadir dalam kehendak Tuhan. Jangan seperti salatnya orang yang mabuk, badannya hadir dalam masjid, akan tetapi hatinya berada di pasar. Lisan (dhahir) membaca fatihah, tapi hatinya bermain cat ur di pasar. Hal seperti itu tidak termasuk dalam Yuqīmūn al-Shalāt, yang mendirikan salat tapi tidak mengerjakan salat.

Oleh sebab itu, hati diperlukan ketika melakukan perintah dari Allah, salah satunya yaitu salat. Menilik kembali penjelasan di atas, bahwa salah satu sifat orang yang bertakwa ialah tetap melaksanakan salat ada atau tidak adanya manusia lain yang menyaksikannya. Ketika seseorang sudah mencapai kadar tersebut maka, dalam salatnya dia akan selalu merasa dilihat oleh Allah. Sehingga dia dapat dengan khusyuk, hudur dan tawadhu ketika saalat.

Kiai Shaleh menambahkan keterangan di atas dengan mengutip hadis Nabi saw., sebagaimana di bawah ini:

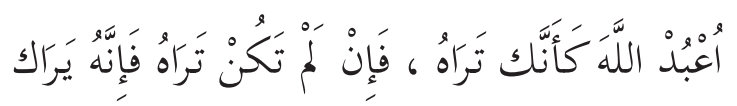

Nyembaho siro ing Allah koyo-koyo siro iku ningali ing Allah Subhanahu wa Ta'ala. ${ }^{62}$

Beribadahlah kepada Allah, seolah-olah kalian melihat Tuhan.

Salat yang dilakukan secara lahir dan batin dapat menjadi sarana untuk menyucikan jiwa. Dengan salat yang seperti ini seseorang akan merasa dekat dengan penciptanya. Akhirnya jiwa dan hati seseorang tersebut akan lebih tenang.

Allah berfirman dalam Surah al-Baqarah ayat 238:

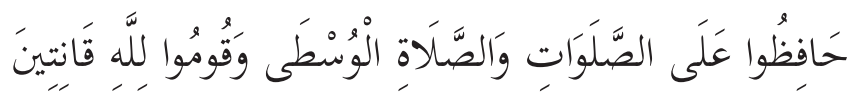

62 Shaleh Darat, Lathāif al-Thaharah wa Asrar al-Shalah...hlm. 37. 
Peliharalah segala salat (mu), dan (peliharalah) salat wustha. Berdirilah karena Allah (dalam salatmu) dengan khusyuk.

Allah memerintahkan kepada manusia untuk selalu menjaga salatnya dengan syarat dan rukun baik bersifat lahir maupun batin tepat pada waktunya, dan juga salatwusthā. Dan dirikanlah salat dengan rasa penuh hormat dan takut kepada-Nya. ${ }^{63}$

Para ulama berbeda pendapat mengenaishalāt al-wusthā. Ada 6 pendapat mengenai hal tersebut, shalāt al-wustha adalah salat subuh, salat zuhur, salat asar, magrib, isya dan di antara dari 5 waktu salat tersebut. Menurut Kiai Shaleh Darat, dengan menghadirkan dari ruh salat maka salat ini dapat dikatakan shalāt al-wustha. Karena yang berada di tengah-tengah manusia adalah hati, dan hati juga menjadi perantara antara jasad dan ruh. ${ }^{64}$

Kehadiran hati sangat penting, karena dengan ini dapat menghidupkan salat. Begitu juga sebaliknya, jika seseorang tidak dapat menghadirkan hati dalam salatnya, maka sama halnya dengan suatu kebinasaan. Untuk tetap mengusahakan sahnya salat, maka para ulama menyatakan bahwa paling sedikitnya ialah kehadiran hati pada takbiratul ihram. ${ }^{65}$

Kiai Shaleh Darat telah menyebutkan ruh daripada salat dalam tafsirnya pada Surah al-Baqarah ayat 3, di antaranya adalah khusyu', tawadhu', hibah, khauf, dan yang pasti adalah shuduq serta ikhlas. Untuk penjelasan lebih detailnya beliau menuangkannya dalam karyanya yang lain, sebagai berikut:

Pertama, hadirnya hati dalam salat. Mengosongkan hati dari semua makhluk dan hanya membayangkan bahwa Allah melihat salatnya dan bahwa semua makhluk berada dalam naungan-Nya. Kedua, mengerti. Maksudnya ialah mengerti apa yang akan dibaca dan makna dari salat. Ketiga, ta'dzim. Mengagungkan Allah secara

63 Shaleh Darat, Faidh al-Raḥmān Fỉ Tarjamah Tafsīr Kalām Malik al-Dayyān...hlm. 439. 64 Shaleh Darat, Faidh al-Rahmān Fỉ Tarjamah Tafsìr Kalām Malik al-Dayyān...hlm. 440-441. 65 Muhammad al-Ghazali,Rahasia-Rahasia Salat...hlm. 62. 
sungguh-sungguh dan jangan sampai membayangkan selain Allah yang mempunyai sifat Agung. Keempat haibah, yaitu takut kepada Allah. Kelima, raja' yaitu mengaharap suatu balasan dari Allah karena takut akan siksa-Nya. Keenam, haya', malu dan merasa tidak dapat memenuhi adab dari salat.

Menurut ahli batin, tidak adanya enam hal di atas dalam melaksanakan salat, maka salat tersebut tidaklah sah. Meskipun syarat dan rukun lahir sudah terpenuhi. Sebaliknya, menurut 'ahli dzahir', salat tersebut sah karena sudah memenuhi ketentuan dari syarat dan rukun salat. Maka orang tersebut tidak dapat dibunuh dan selamat hartanya. ${ }^{66}$

Termasuk juga adab dalam salat adalah sabar, tawaduk, khusyuk dan hudur dalam salat. Allah berfirman :

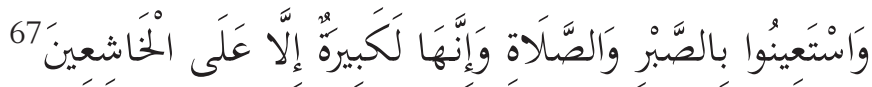

"Dan mohonlah pertolongan (kepada Allah) dengan sabar dan salat. dan (salat) itu sungguh berat, kecuali bagi orang-orang yang khusyu."

Hubungan antara sabar dan salat, Allah telah berfirman yang terkandung dalam Surah al-Baqarah ayat 153:

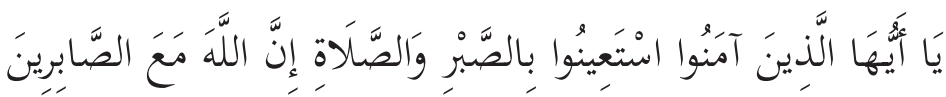

Artinya : Hai orang-orang yang beriman, mintalah pertolongan (kepada Allah) dengan sabar dan (mengerjakan) salat, sesungguhnya Allah beserta orang-orang yang sabar.

Seorang mukmin haruslah selalu zikir dan bertafakur kepada Allah, serta meninggalkan kekufuran. Sikap sabar diperlukan baik ketika mendapat sebuah cobaan dari Allah maupun ketika melaksanakan sebuah ibadah, termasuk di dalamnya adalah salat. Karena kelak akan memberikan pertolongan serta taufik terhadap orang-orang yang sabar.

66 Shaleh darat, Majmu' al-Syari'at al-Kāfiyat li al-'Awam...hlm. 67.

67 QS. Al-Baqarah [2]: 45 
Allah akan memberikan taufik terhadap seorang mukmin karena dia zikir dan syukur kepada Allah, serta menjauhi dari segala bentuk maksiat. Bentuk syukur juga bisa dengan merasa bahwa dirinya kurang berunt ung karena tidak bisa syukur atas nikmat-nikmat yang telah Allah berikan kepadanya. Oleh karena itu mintalah pertolongan kepada Allah dengan sabar dan selalu melaksanakan ibadah salat.

Menurut Kiai Shaleh Darat, sabar adalah perbuatan dari hati, sedangkan salat adalah perbuatan yang dilakukan oleh badan. Untuk mencapai kategori orang yang bersyukur, maka diperlukan adanya sabar dalam melakukan salat. Artinya, antara hati dan badan harus selaras dan sama-sama menghayati ketika menjalankan salat. ${ }^{68}$

Setelah melakukan sistematika salat secara lahir maupun batin, dengan menghadirkan ruh-ruh salat termasuk juga adab di dalamnya, maka seseorang tersebut akan mendapatkan janji Allah, seperti yang tertuang dalam Surah al-Baqarah ayat 277:

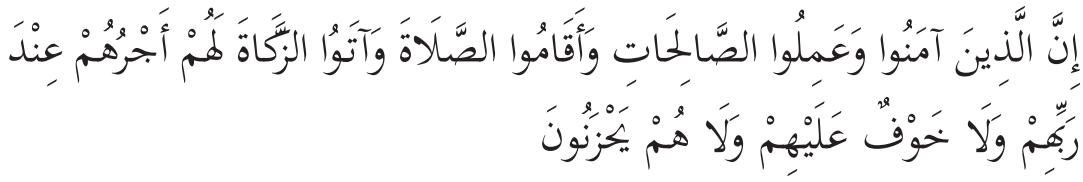

"Sesungguhnya orang-orang yang beriman, mengerjakan amal saleh, mendirikan sembahyang dan menunaikan zakat, mereka mendapat pahala di sisi Tuhannya. Tidak ada kekhawatiran terhadap mereka dan tidak (pula) mereka bersedih hati."

Selain hikmah di atas ini, sebagian ulama dan Kiai Shaleh Darat menjelaskan hikmah dari setiap gerakan dan aspek-aspek yang detail dalam salat, sebagai berikut:

\section{a. Menunaikan janji kepada Allah}

Sebelum manusia lahir ke dunia fana, mereka terlebih dahulu melakukan perjanjian dengan Tuhannya selagi di alam arwah. Isi perjanjian itu adalah meyakinkan dirinya bahwa Allah selalu hadir di manapun mereka berada, dan Allah lebh dekat dari pada urat nadi

68 Shaleh Darat, Faidh al-Raḥmān Fī Tarjamah Tafsīr Kalām Malik al-Dayyān, hlm. 391. 
mereka. Kemudian akan memenuhi janji rububiah dalam bentuk ubudiah. ${ }^{69}$

Karena sudah sejak berada di alam azali, manusia sudah diberikan amanah dari Allah. Bentuk amanah ini yaitu dengan beriman kepadaNya ketika sudah berada pada dunia fana. Dalam Alquran disebutkan bahwa:

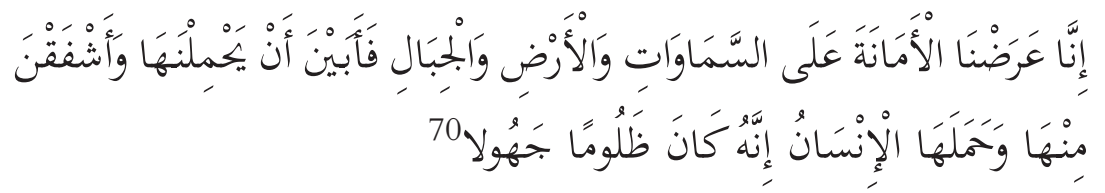

Artine: Setuhune ingsun wis mintoaken ingsun ing amanah, tegese agomo Islam, ingsun pitoaken ingatase pitung langit lan bumi lan piro-piro gunung moko ora ono podo puat mikul ing amanah ingsun, podo wedi kabeh langit, bumi, gunung saking mikul ing amanah. moko saguh mikul ing amanah manungso anak adam moko dadi ono iki atine menungso perantine wadah ngamut ing amanahe Allah. ${ }^{71}$

Artinya: sesungguhnya kami telah memberikan amanah, yaitu agama Islam, kami memberikan amanah kepada 7 langit, bumi dan beberapa gunung, akan tetapi tidak ada sat upun yang mampu dan berani untuk mengemban amanah dari Allah. Hanya manusia yang dapat mengemban amanah dari Allah, sehingga sudah ditetapkan bahwa hati manusia sebagai wadah daripada mengemban amanah Allah.

\section{b. Terbebas dari sifat-sifat madzmumah}

Ada 4 derajat dalam salat, yaitu berdiri (qiyam), rukuk, sujud, dan tasyahud. Pertama, tasyahud. Derajat ini diibaratkan dengan jamadiah, yaitu segala sesuatu yang keras, tidak dapat tumbuh dan berkembang serta merupakan benda mati. Kedua, sujud. Kiai Shaleh Darat mengibaratkan dengan nabatiyah, yaitu bersifat tumbuhan, yang tumbuh dan berkembang. Ketika seseorang sudah melakukan sujud secara lahir dan batin, maka dia akan selamat dari cobaan dari

69 Shaleh Darat, Faidh al-Raḥmān Fì Tarjamah Tafsìr Kalām Malik al-Dayyā, hlm. 34.

70 QS. al-Ahzzab [33] : 72

71 Shaleh Darat, Lathāif al-Thaharah wa Asrar al-Shalah, hlm. 62. 
bangsa tanaman. ${ }^{72}$ Bentuk dari cobaan ini adalah tertarik terhadap sesuatu selain yang berhubungan dengan Allah, dan suka dengan kenaikan, seperti kenaikan pangkat, semakin dihormati dan lain sebagainya ${ }^{73}$ Ketiga, rukuk. Derajat ini isyarat terhadap hewan. maka dia akan terhindar dari sifat-sifat hewan, seperti hati yang dikuasai oleh hawa dan syahwat. ${ }^{74}$ Keempat, berdiri (qiyam). Derajat ini isyarat dari ibadahnya manusia. Ketika seseorang melakukan qiyam untuk salat secara lahir dan batin, serta adanya rasa tawaduk, maka dia akan terbebas dari sifat merasa besar dan riya. ${ }^{75}$

c. Mencegah kejelekan

Seperti yang Kiai Shaleh Darat jelaskan dalam kitab tafsirnya bahwa:

"Lan maleh den perintahaken mukmin kabih kapurih amrih pitulung kelawan solat. kerono solat dadi bisa nyegah ingatase fahsya lan ngedohi mungkar. Podo amriho siro kabeh ingatase oleh iro amrih haq lan tinggal batil kelawan sabar ingatase tinggal syahwate nafsu lan ingatase oleh tinggal hawa. Lan maleh amriho pitulung siro kabeh ingatase amrih haq kelawan solat."

..dan sudah diperintahkan bagi semua orang mukmin untuk meminta pertolongan Allah melalui salat. Karena dengan salat dapat mencegah sesuatu yang jelek dan menjauhkan dari yang munkar. Oleh sebab itu, carilah segala sesuatu yang haq dan meninggalkan kebatilan dengan melakukan sabar dan salat.

d. Mendapat pahala sebanyak sayap dari malaikat

Salat yang wajib dilaksanakan sehari semalam adalah 5 kali. Dari setiap salat tersebut, ada yang terdiri dari 2 rakaat, 3 rakaat dan 4 rakaat. Jumlah rakaat ini diibaratkan dengan sayap daripada malaikat Allah yang jumlahnya ada yang 2, 3, dan 4 sayap. Seperti

72 Shaleh Darat, Faidh al-Raḥmān Fì Tarjamah Tafsìr Kalām Malik al-Dayyān, hlm. 35.

73 Shaleh Darat, Lathāif al-Thaharah wa Asrar al-Shalah, hlm. 36.

74 Shaleh Darat, Lathāif al-Thaharah wa Asrar al-Shalah, hlm. 36.

75 Shaleh Darat, Faidh al-Rahmān Fì Tarjamah Tafsìr Kalām Malik al-Dayyān, hlm. 35.

76 Shaleh Darat, Faidh al-Raḥmān Fī Tarjamah Tafsīr Kalām Malik al-Dayyān, hlm. 141. 
yang tertulis dalam Alquran:

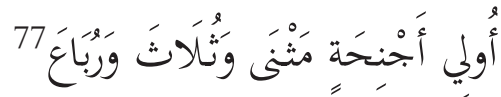

Artine: setuhune malikat kabeh iku podo anduweni suwiwi luru-luru lan ono ingkang telu-telu lan ono ingkang papat-papat.

Artinya: Sesungguhnya malaikat terbang dengan sayap-sayapnya, sedangkan manusia akan terbang dengan salatnya, maksudnya dengan rakaat-rakaat salatnya.

Sehingga jika seseorang melakukan salat 5 waktu akan sederajat dengan ibadahnya para malaikat. Dengan qiyam, rukuk, sujud dan tasyahud yang merupakan bentuk dari ibadahnya makhluk Allah, maka jika semua itu dilakukan manusia tersebut menjadi sebaiksebaik makhluk. ${ }^{78}$ Jika manusia sudah melakukan salat dengan tata cara yang benar serta menghadirkan hatinya dalam melaksanakan salat, maka dia sudah menepati janji dan amanah yang diberikan oleh Allah. Keuntungan manusia jika sudah melakukan hal ini adalah dia termasuk dari sebagus-bagus manusia (khair al-Bariyyah) ${ }^{79}$

Seseorang akan mendapat derajat mulia di sisi Tuhannya dengan melaksanakan ibadah salat. Seperti yang telah dijelaskan di atas, bagaimana tata cara salat sampai hikmah salat. Yang mana dalam melakukan ibadah ini harus sepenuh hati atau dengan kata lain salat tidaklah cukup dianggap hanya untuk memenuhi syarat dan rukun lahir saja, melainkan juga harus menyempurnakan syarat dan rukun batin juga, sehingga nantinya dalam salat tersebut terdapat ruh salat. Dengan begitu, maka seseorang tersebut akan menjadi makhluk yang paling mulia.

\section{F. Telaah atas Pemikiran Kiai Shaleh Darat}

Seiring dengan kemajuan yang ada di Semarang, pihak kolonial Belanda juga memasukkan misi menyebarkan agama Kristen.

77 QS. Fathir ayat [35] : 1

78 Shaleh Darat, Lathāif al-Thaharah wa Asrar al-Shalah, hlm. 42.

79 Shaleh Darat, Lathāif al-Thaharah wa Asrar al-Shalah, hlm. 62. 
Kristenisasi di kota ini ditandai dengan berdirinya beberapa gereja. Salah satunya adalah yang didirikan di Gedangan oleh Pastor J. Leynen sekitar tahun $1876 .{ }^{80}$ Di sisi lain, kebiasaan masyarakat yang kurang baik, seperti berjudi, mabuk-mabukan semakin marak dengan adanya pendatang asing. Kebiasaan tersebut merupakan hal yang biasa bagi mereka. Guna memudahkan masyarakat dalam berjudi, kemudian dibangunlah tempat gadai, agar para penjudi lebih cepat dalam mendapat uang. ${ }^{81}$

Sistem kolonial Belanda ini dianggap sebagai penyebab kurang berkembangnya ajaran-ajaran Islam di Indonesia, khususnya di Semarang. Pada umumnya agama Islam dianggap sebagai suatu unsur yang membahayakan pemerintah kolonial. Maka pergerakan kerajaan-kerajaan Islam dipersempit dalam misi dakwahnya. Seperti dibekukannya tiga kesultanan Islam, yaitu Palembang, Aceh dan Banjarmasin. Ketiga kesultanaan ini sebelumnya menjadi pusat dari studi Islam di Indonesia. Dengan itu, maka lembaga-lembaga yang secara formal sebagai penyokong berkembangnya ajaran Islam juga dibekukan. ${ }^{82}$

Melihat kenyataan ideologi masyarakat yang jauh dari kehidupan Islam, maka Kiai Shaleh Darat hadir dengan misi mengislamkan perilaku masyarakat tersebut. Usaha Islamisasi ini dilakukannya melalui majelis-majelis dan juga dengan karya tulisnya. Pola pemikiran seorang Kiai Shaleh Darat bisa dikatakan lebih bernuansa sufistik, baik ketika beliau mengisi majelis-majelis ataupun dalam karya-karyanya. Cara berpikir Kiai Shaleh Darat yang banyak bernuansa sufi ini tentunya tidak lahir dari pemikirannya sendiri, melainkan dipengaruhi oleh beberapa unsur, di antaranya guru-guru beliau serta kitab-kitab yang diajarkan oleh guru-guru tersebut.

80 Ghazali Munir, Warisan Intelektual Islam Jawa (Semarang: Walisongo Press, 2008),hlm.

4 mengutip dari Jongkie Tio, Kota Semarang dalam Kenangan,hlm. 16-17.

81 Ghazali Munir, Warisan Intelektual Islam Jawa,hlm. 4 mengutip dari Jongkie Tio, Kota Semarang dalam Kenangan,hlm. 20.

82 Karel A. Steenbrink, Pesantren Madrasah Sekolah Pendidikan Islam dalam Kurun Modern(Jakarta: LP3ES, 1986), hlm. 6-7 dalam Ghazali Munir, Warisan Intelektual Islam Jawa, hlm. 4-5. 
Kiai Shaleh Darat mempelajari kalam (teologi) kepada Sayyid Syaikh ibn Ahmad Bafaqih Ba'alawi ${ }^{83}$ ketika di Semarang dengan kitab Jauhar al-Tauhid karya Ibrahim al-Laqani dan kitab Minhaj al'Abidin karya dari Imam al-Ghazali. Ketika beliau menuntut ilmu di Mekah, Kiai Shaleh Darat belajar Umm al-Barahin karya Muhammad al-Sanusi dan Hasyiyah-nya karya dari Syaikh Ibrahim Bajuri kepada Syaikh Muhammad al-Muqri al-Misri al-Makki, dan ketika belajar kitab Syarh al-Khatib, Fath al-Wahhab, Alfiyah ibn Malik beserta syarh-nya sampai mendapatkan ijazah dari gurunya yang bernama Syaikh Muhammad ibn Sulaiman Hasb Allah seorang pengajar di Mekah dan Madinah. Guru-guru ini memiliki silsilah yang sampai pada Ibrahim ibn Muhammad Baijuri pengarang kitab Tuhfat al-Murid syarah dari kitab Jauhar al-Tauhid dan Syaikh al-Syurqawi pengarang dari kitab Syarh al-Hikām. ${ }^{84}$

Kemudian tidak heran jika kebanyakan karya dari Kiai Shaleh Darat bernuansa sufistik, di antaranya adalah Kitab Munjiyāt Metik sakingIhya 'ulūm al-Dīn al-Ghazali, Kitab Matn al-Hikam, Kitab Lathāif al-Thahārah wa Asrār al-Sholāh, Manāsik al-Hajj wa al'Umrah, Kitab minhaj al-Atqiya' Fì Syarh Ma'rifah al-Azkiya' dan Faidh al-Raḥmān Fì Tarjamah Tafsīr Kalām Malik al-Dayyān.

Dilihat dari karya tafsirnya, Kiai Shaleh menjadikan karya dari Imam al-Ghazali sebagai salah satu rujukannya. Selain itu, tafsir ini merujuk juga pada beberapa karya tafsir lainnya, seperti Tafsir al-Jalalain karya dari Imam Jalal al-Din al-Mahalli dan Imam Jalal al-Din al-Suyuthi, Tafsir Anwar al-Tanzil wa Asrar al-Ta'wil, karya Imam Abdullah ibn Umar al-Baidhowi, Lubab al-Ta'wil fí Ma;ani al-Tanzil, karya Syaikh 'Ala' al-Din al-Khazin. ${ }^{85}$

Corak dari penafsiran Kiai Shaleh Darat dapat dikategorikan sebagai tafsir isyari. Beliau sendiri menuliskannya secara jelas dalam tafsirnya dengan kata ma'na al-'isyari, sebagai pembeda antara arti

83 Shaleh Darat,al-Mursyìi al-Wajiz, hlm. 277.

84 Ghazali Munir, Warisan Intelektual Islam Jawa,hlm. 45.

85 Shaleh Darat, Faidh al-Rahmmān Fī Tarjamah Tafsīi Kalām Malik al-Dayyā, hlm. 1. 
dari ayat tersebut dengan tafsir yang akan beliau tuliskan. Adapun metode tafsir yang beliau gunakan adalah metode ijmali; yaitu metode tafsir yang menjelaskan ayat Alquran yang bersifat global.

Dengan menggunakan metode ijmali dirasa sesuai bagi kalangan awam, yang menjadi target dakwah Kiai Shaleh Darat. Seperti yang sudah sering beliau utarakan dalam mukadimah-mukadimah kitabnya. Selain itu, bahasa yang digunakan juga sesuai dengan bahasa daerah setempat, yaitu bahasa Jawa. Dengan bahasa tersebut, akan lebih memudahkan dalam menyampaikan pesan-pesan Alquran, karena bahasa Jawa adalah bahasa masyarakat yang menjadi objek dakwahnya. Tujuan sederhananya adalah untuk membantu masyarakat awam yang kurang memahami bahasa Arab agar bisa menangkap pesan-pesan Alquran.

Metode penyampaian menggunakan bahasa Jawa dengan aksara Arab ini bisa jadi bentuk dari menolak kolonialisme Belanda. Bahwasannya, saat itu sedang gencar-gencarnya mensosialisasikan aksara Roman kepada masyarakat Jawa sebagai tulisan yang formal. Karena mereka juga bertujuan menggunakan aksara Roman sebagai aksara yang akan digunakan dalam kehidupan sehari-hari di Jawa. ${ }^{86}$ Padahal, sebelumnya masyarakat menggunakan aksara Arab dengan bahasa Melayu-Jawa dalam keseharian mereka.

Tidak menutup kemungkinan bahwa ketika Kiai Shaleh Darat mempunyai konsep salat yang sedemikian rupa merupakan ijtihadnya sendiri. Ijtihad yang dilakukan Kiai Shaleh Darat ialah membahasakan ulang karya-karya ulama sebelumnya, seperti karya dari al-Ghazali mengenai rahasia-rahasia yang terkandung dalam salat. Menurut Abdul Mustaqim dalam risetnya, ia menyebutkan bahwa kemungkinan Kiai Shaleh Darat merujuk dari kitab Ihya' 'Ulum al-Dīn dan Jawahir Alquran karena dari kedua kitab tersebut, Imam al-Ghazali banyak menyebutkan penafsirannya yang bersifat isyari dari ayat-ayat Alquran. ${ }^{87}$

86 Islah Gusmian, "Bahasa dan Aksara Tafsir Alquran di Indonesia" dalam Jurnal Tsaqofah, Vol. 6, No. 1, April 2010, hlm. 6.

87 Abdul Mustaqim, Epistemologi Khazanah Tafsir Jawa, Ringkasan Riset,Yogyakarta, 
Dalam Kitab Asrār al-Shalāt yang merupakan salah satu bab dalam Ihya' 'Ulum al-Dīn karya al-Ghazali misalnya, disebutkan bahwa ruh salat ada 6 , di antaranya yaitu kehadiran hati, tafahhum, ta'dzim, haibah, raja' dan haya' ${ }^{88}$ Penjelasan ini sama dengan apa yang telah dituangkan Kiai Shaleh Darat mengenai term salat, seperti yang sudah dijelaskan sebelumnya.

Bukan hanya mengenai ruh salat, kemiripan pemikiran antara Kiai Shaleh Darat dengan al-Ghazali juga terlihat ketika membahas tentang perlunya kehadiran hati dalam melaksanakan salat. Dimana salat tersebut dapat dikatakan sah jika dalam mengerjakannya, hati dari orang tersebut ikut hadir di dalamnya.

Menurut al-Ghazali, hakikat salat adalah bermunajat (berbincangbincang) antara makhluk dengan Tuhannya. Sedangkan dalam perbincangan tersebut tidak dapat dikatakan sebuah perbincangan apabila dalam keadaan lengah. ${ }^{89}$ Tidak jauh beda dengan pemikiran Kiai Shaleh Darat, menurutnya tidak dikatakan salat jika dalam melaksanakannya pikiran dari seseorang masih memikirkan sesuatu selain Allah. Beliau mengistilahkan hal tersebut sebagai salatnya seseorang yang mabuk. ${ }^{90}$ Tidak hanya itu, orang yang mabuk ketika salat (sukarā) oleh al-Ghazali diartikan sebagai seseorang yang hatinya masih terisi dengan cinta terhadap dunia serta pikirannya yang tidak fokus ketika salat. ${ }^{91}$ Penafsiran ini tidak jauh berbeda dengan penafsiran Kiai Shaleh Darat, beliau mengartikan sukarā dengan orang yang lisannya membaca fatihah akan tetapi hatinya memikirkan pasar. $^{92}$

Contoh di atas, mengindikasikan bahwa bisa jadi Kiai Shaleh Darat mengutip beberapa pernyataan dalam Asrār al-Shalāt karya

2015, tidak Dipublikasikan, hlm. 58

88 Muhammad al-Ghazali, Rahasia-Rahasia Salat, terj.Muhammad al-Baqir (Bandung:

Karisma, 1999), hlm. 61-63.

89 Muhammad al-Ghazali, Rahasia-Rahasia Salat...hlm. 56.

90 Shaleh Darat, Faidh al-Rậmān Fī Tarjamah Tafsīr Kalām Malik al-Dayyān, hlm. 33

91 Muhammad al-Ghazali, Ihyya' 'Ulum al-Dīn, (Mesir: al-Syirkah al-Nūr Āsiyā, tt), Juz. 1,

hlm. 149.

92 Shaleh Darat, Faidh al-Raḥmān Fì Tarjamah Tafsīr Kalām Malik al-Dayyān, hlm. 33. 
al-Ghazali. Karena beliau tidak menjelaskan kutipan-kutipannya secara jelas. Akan tetapi, tidak menutup kemungkinan juga bahwa di sana terdapat beberapa hasil pemikiran Kiai Shaleh Darat sendiri. Sesungguhnya konsep salat seperti yang diungkapkan Kiai Shaleh Darat bukanlah sesuatu yang baru. Di mana ketika salat, kehadiran hati sangat diperlukan sebagai penyempurna salat. Jauh sebelum Kiai Shaleh Darat menyusun konsep salat seperti di atas, terdapat karyakarya ulama sebelumnya yang juga mengusung konsep salat seperti halnya beliau, di antaranya al-Ghazali dalam kitabnya Ihya' 'Ulum al-Din, kemudian Syeikh Abdul Qadir al-Jilani dalam Kitab Tafsirnya Tafsir al-Jilāni, di mana konsep tersebut dikumpulkan dalam sebuah skripsi. ${ }^{93}$ Dalam kitab tafsīr al-Jilāni, syekh 'Abd al- Qādir al-Jilāni menafsirkan kata وَالصَّلَاِِالْوُسْـَ diartikan dengan sarana menghadap kepada Allah secara batiniyah yang muncul di antara dua hembusan nafas. ${ }^{94}$

Dari keterangan di atas, maka dapat dikatakan bahwa pemikiran Kiai Shaleh Darat mengenai salat sejalan dengan pemahamanpemahaman sebelumnya. Dan juga pemikiran Kiai Shaleh Darat dapat dikatakan benar dengan mengacu pada teori kebenaran, yaitu sesuai dengan teori koherensi. Dimana sebuah penafsiran dianggap benar, jika ia sesuai atau sejalan dengan pemahaman sebelumnya, serta konsisten dalam menerapkan metodologi yang digunakan oleh mufasir. $^{95}$

Maka pemikiran Kiai Shaleh Darat dapat dikatakan benarmengacu pada teori koherensi- bahwa konstruksi pemikirannya tidaklah bertentangan dengan pemahaman-pemahaman mengenai salat sebelumnya. Kemudian, Kiai Shaleh Darat juga konsisten dalam metodologinya. Hal ini dapat dilihat dari corak tafsirnya yang sufistik.

93 Siti Tasrifah, Konsep Salat Menurut Syaikh Abd al-Qadir al-Jilani, Skripsi, Jurusan Ilmu Alquran dan Tafsir, Fakultas Ushuluddin, UIN Sunan Kalijaga, 2016.

94 'Abd al- Qādir Al Jilānì, Tafsìr Al Jilānì (Ed ) Ahmad Farid al-Mazìdi (Beirut: Dār alKutub al-'Ilmiyah, 2014 ), jld. 1, hlm.221.; dalam Siti Tasrifah, Konsep Salat Menurut Syaikh Abd al-Qadir al-Jilani, hlm. 3.

95 Abdul Mustaqim, Dinamika Sejarah Tafsir Alquran, (Yogyakarta: Adab Press, 2012), hlm. 187. 


\section{G. Penutup}

Dari penelitian yang telah dilakukan maka penulis dapat menarik kesimpulan yang menjadi jawaban dari rumusan masalah, bahwa penafsiran Kiai Shaleh Darat mengenai ayat-ayat tentang salat adalah sebagai berikut:

Dalam melakukan salat, seseorang harus menghadirkan hati di dalamnya. Kemudian, berusaha menghadirkan ruh salat yang ada 6 di ant arnya yaitu Pertama, hadirnya hati dalam salat. Mengosongkan hati dari semua makhluk dan hanya membayangkan bahwa Allah melihat salatnya dan bahwa semua makhluk berada dalam naunganNya. Kedua, mengerti, maksudnya ialah mengerti apa yang akan dibaca dan makna dari salat. Ketiga, ta'dzim, mengagungkan Allah secara sungguh-sungguh dan jangan sampai membayangkan terdapat selain Allah yang mempunyai sifat Agung. Keempat haibah, yaitu takut kepada Allah. Kelima, raja' yaitu mengaharap suatu balasan dari Allah karena takut akan siksa-Nya. Keenam, haya', malu dan merasa tidak dapat memenuhi adab dari salat. dalam melakukan ibadah ini harus sepenuh hati atau dengan kata lain salat tidaklah cukup hanya memenuhi syarat dan rukun lahir saja, melainkan juga harus menyempurnakan syarat dan rukun batin juga, sehingga nantinya dalam salat tersebut terdapat ruh salat. Dengan begitu, maka seseorang tersebut akan menjadi makhluk yang paling mulia.

Hasil pemikiran Kiai Shaleh Darat mengenai salat yang sedemikian rupa ialah bentuk reaksi dari kondisi ideologi masyarakat pada saat itu, yang jauh dari kehidupan Islami. Sedangkan dalam menafsirkan ayat-ayat salat, Kiai Shaleh Darat mengutip dan menukil penjelasan dari mufassir sebelumnya, di antaranya yaitu Tafsir al-Jalalain karya dari Imam Jalal al-Din al-Mahalli dan Imam Jalal al-Din al-Suyuthi, Tafsir Anwar al-Tanzil wa Asrar al-Ta’wil, karya Imam Abdullah ibn Umar al-Baidhowi, Lubab al-Ta'wil fī Ma;ani al-Tanzil, karya Syaikh 'Ala' al-Din al-Khazin. Selain itu, sebagai sumber rujukan dari Kiai Shaleh Darat dalam menafsirkan ayat-ayat tentang salat ialah karyakarya dari Imam al-Ghazali, seperti Asrār al-Shalāt, Ihya' 'Ulum al- 
Dīn dan Jawahir Alquran. Dalam mengutip atau menukil pendapat tersebut, beliau kemungkinan mengutip keseluruhan dan bisa jadi sebagian saja sesuai dengan tema pembahasan.

\section{DAFTAR PUSTAKA}

Izzan, Ahmad . Metodologi Ilmu Tafsir. Bandung: Tafakur, 2011.

A. Steenbrink, Karel. Pesantren Madrasah Sekolah Pendidikan Islam dalam Kurun Modern. Jakarta: LP3ES. 1986.

Azra, Azyumardi. Jaringan Ulama Timur Tengah dan Kepulauan Nusantara Abad XVII dan XVIII. Jakarta: Kencana. 2013.

Darat, Shaleh. Faị̣ al-Rahmān Fī Tarjamah Tafsīr Kalām Malik alDayyān. Semarang: Toha Putera. t.th.

. Lathāif al-Ṭahārat wa Asrār al-Sholāh Fì Kaifiyat Sholāt al-Ābidin wa al-Arifîn. Semarang: Toha Putera. t.th.

. Majmu'at al-Syari 'at. Semarang: Toha Putera. t.th.

. Matn al-Hikam. Semarang:Toha Putera. t.th.

. Majmu'at al-Syari'at al-Kāfiyat Lì al-'Awām. Semarang: Toha Putera. t.th.

. Kitab Munjiyāt Metik Saking Ihya 'ulūm al-Dīn al-Ghazali. Semarang: Toha Putera. t.th.

-Kitab Manasik al-Hajj wa al-'Umrah. Bombay: al-Karimi alWaqi'. $1340 \mathrm{H}$.

. Kitab Tarjamah Sabil al-'Abid 'Ala Jauharah al-Tauhìd. Cirebon: al-Misriyyah. 1896.

.Kitab Minhaj al-Atqiya' Fī Syarh Ma'rifah al-Azkiya'. Bombay: Muhammadi. $1317 \mathrm{H}$.

. Faidh al-Rạ̣mān Fī Tarjamah Tafsìr Kalām Malik alDayyān (Singapura: Haji Muhammad Amin, 1311 H).

.Hidāyat al-Raḥman. Semarang: al-Munur. 1935. 
Faiz, Fahruddin. Hermeneutika Alquran: Tema-Tema Kontroversial. Yogyakarta: eLSAQ Press. 2011.

Ghazali, Muhammad al-. Rahasia-Rahasia Salat. terj. Muhammad al-Baqir. Bandung: Karisma. 2003.

Gusmian, Islah. Khazanah Tafsir Indonesia. Yogyakarta: LKiS Yogyakarta. 2013.

Harun, Salman. Mutiara Alquran. Jakarta: Logos. 1999.

Kholilatul Ummi, Za'im. "Kajian Tafsir Faị̣ al-Rahmān Fī Tarjamah Tafsīr Kalām Malik al-Dayyān” dalam situs Academia.edu yang diunduh pada 23 Oktober 2015 pukul 20.47 wib.

Manshur, Abdul Qadir Muhammad. Panduan Salat Khusus Wanita: Salat yang Benar Menurut Alquran dan As-Sunnah. Jakarta: Almahira. 2009.

Mas'ud, Abdurrahman. Intelektual Pesantren Perhelatan Agama dan Tradisi. Yogyakarta: LKIS. 2004.

Masyhuri, A. Aziz. 99 Kiai Kharismatik Indonesia, Biografi, Perjuangan, Ajaran dan Doa-Doa Utama yang Diwariskan. Yogyakarta: Kutub. 2008.

Munir, Ghazali. Warisan Intelektual Islam Jawa. Semarang: Walisongo Press. 2008.

Muqaddam, Muhammad al-. Kenapa Harus Salat. Solo: Aqwam. 2007. Musbikin, Imam. Mutiara Alquran. Madiun: Jaya Star Nine. 2014. Mustaqim, Abdul. Metode Penelitian Alquran dan Tafsir. Yogyakarta: Idea Press. 2014.

. Epistemologi Khazanah Tafsir Jawa. Ringkasan Riset. Yogyakarta. 2015. Tidak Dipublikasikan.

Shabir, Muslich. "Studi Kitab Minhaj al-Atqiya'suatu Upaya Untuk Mengungkap Pemikiran Tasawuf Kyai Saleh Darat”. IAIN Walisongo Semarang. 2005.

Shihab, M. Qusraish. Kaidah Tafsir. Tangerang: Lentera Hati. 2013. 
Surur, Misbahus. "Metode dan Corak Tafsir Faidh Ar-Rahman Karya Muhammad Shaleh Darat As-Samarani”.IAIN Walisongo Semarang. 2011.

Uddin, Chiba. "Pemikiran Kiai Saleh Darat Tentang Pernikahan (Telaah Rukun dan Syarat Nikah Dalam Kitab Majmu'ah alSyariah".Fakultas Syari'ah UIN Sunan Kalijaga Yogyakarta. 2003.

Zuhdi, M. Nurdin Zuhdi. Pasaraya Tafsir Indonesia. Yogyakarta: Kaukaba Dipantara. 2014.

Tasrifah, Siti. Konsep Salat Menurut Syaikh Abd al-Qadir al-Jilani. Fakultas Ushuluddin UIN Sunan Kalijaga Yogyakarta. 2016.

Mustaqim, Abdul. Dinamika Sejarah Tafsir Alquran. Yogyakarta: Adab Press. 2012. 